Marian A. GIŻEJOWSKI ${ }^{1}$

Albashir Ali K. SALEH ${ }^{2}$

Wioleta BARCEWICZ ${ }^{3}$

Jacek UZIAK ${ }^{4}$

\title{
EFFECT OF POSTLIMITING BEHAVIOUR OF ISOLATED BEAM-TO-COLUMN JOINTS OBSERVED IN FORCE CONTROLLED EXPERIMENTS
}

\begin{abstract}
It has been observed that steel and composite steel-concrete beam-to-column joints exhibit in general three main regions of their behaviour, namely a quasi-elastic region at which the joint initial stiffness can be conveniently measured, an inelastic region at which the joint stiffness degrades from its initial value to that corresponding to the joint quasi-plastic moment resistance, and finally a postlimiting region at which the joint stiffness maintains its low value but sufficiently high in order to allow for the joint to reach its ultimate moment resistance. The results of experimental moment-rotation characteristics are used in the Continuous Stiffness Degradation model (CSD model) in which the functions describing the joint moment-rotation characteristic and its first derivative (tangent stiffness) are continuous and take into account the effect of joint postlimiting behaviour modelling of joint characteristics. The accuracy of such modelling is herein examined and discussed. An analytical formulation is presented together with its limitations with regard to adequacy of experimental data available from the force controlled tests conducted at the Warsaw University of Technology. The scope of these tests included three groups of specimens with isolated beam-to-column joints and with a different reinforcement ratio in the hogging region of the reinforced concrete slab.
\end{abstract}

Key words: steel joint, steel-concrete joint, moment-rotation characteristic, postlimit behaviour

${ }^{1}$ Autor do korespondencji: Marian A. Giżejowski, Warsaw University of Technology, Faculty of Civil Engineering, ul. Armii Ludowej 16, 00-637 Warszawa, tel: +48 228258421 , m.gizejowski@il.pw.edu.pl

2 Albashir Ali K. Saleh, Warsaw University of Technology, Faculty of Civil Engineering, ul. Armii Ludowej 16, 00-637 Warszawa, tel. +48 661604 864, b.saleh@il.pw.edu.pl

${ }^{3}$ Wioleta Barcewicz, Warsaw University of Technology, Faculty of Civil Engineering, ul. Armii Ludowej 16, 00-637 Warszawa, tel. +48 22825 5249, w.barcewicz@il.pw.edu.pl,

${ }^{4}$ Jacek Uziak, University of Botswana, Faculty of Engineering and Technology, Private Bag UB 0022, Gabarone, Botswana, (+26) 7355 4304, UZIAK@mopipi.ub.bw 


\section{Introduction}

Investigations on the behaviour of steel and steel-concrete joints have been carried out extensively even longer than in the last decade and are well documented in databases [1].

The behaviour of a certain class of beam-to-column joints has also been investigated experimentally and analytically in Poland, the most extensively within the PhD projects at the Rzeszów University of Technology [2] and at the Warsaw University of Technology [3]. The results of latter investigations will be considered hereafter in a detailed modelling of the moment-rotation characteristics taking into account the effect of postlimiting behaviour of beamto-column joints that has also been observed in tests carried out for a robustness assessment of the behaviour of steel and steel-concrete composite joints tested in two-bay plane frame specimens [4]. The present study is carried out as a part of research within the PhD study of the second author [5].

The current study is the extension of the previous investigations with results presented before [6, 7]. Experimental investigations carried out previously at the Warsaw University of Technology [3] are summarized hereafter. This paper is a result of investigations done within the statutory grant at the Warsaw University of Technology in collaboration with the University of Botswana. The main objective of present research is to study the effect of postlimiting behaviour that was not considered in earlier studies [3]. Furthermore, the aim is to propose an analytical Continuous Stiffness Degradation model (CSD model) in which the functions describing the joint moment-rotation characteristic and its first derivative (tangent stiffness) are continuous and take into account the effect of joint postlimiting behaviour. The developed model allows for the calibration of joint overstrength by the utilization of experimental data reported in [3].

\section{Brief summary of experimental investigations}

\subsection{Specimens and procedure}

Three groups of isolated joint beam-to-columns specimens were tested at the Warsaw University of Technology with a different reinforcement ratio in the hogging region of the reinforced concrete slab. These are, Group 0 consisting of steel joints (referred to as the witnesses for composite joints), Group 1 consisting of steel-concrete composite joints of the reinforcement ratio $\rho=0.60 \%$ (rebars of $10 \mathrm{~mm}$ in diameter), Group 2 consisting of composite joints of the reinforcement ratio $\rho=1.35 \%$ (rebars of the same number but with $12 \mathrm{~mm}$ in diameter) and finally Group 3 consisting of composite joints of the reinforcement ratio $\rho=0.35 \%$ (the same number of rebars but with minimal 
diameter of $6 \mathrm{~mm}$ ). Test stand equipped with a joint composite cruciform specimen, symmetrically loaded and prepared for testing, is presented in Fig. 1.

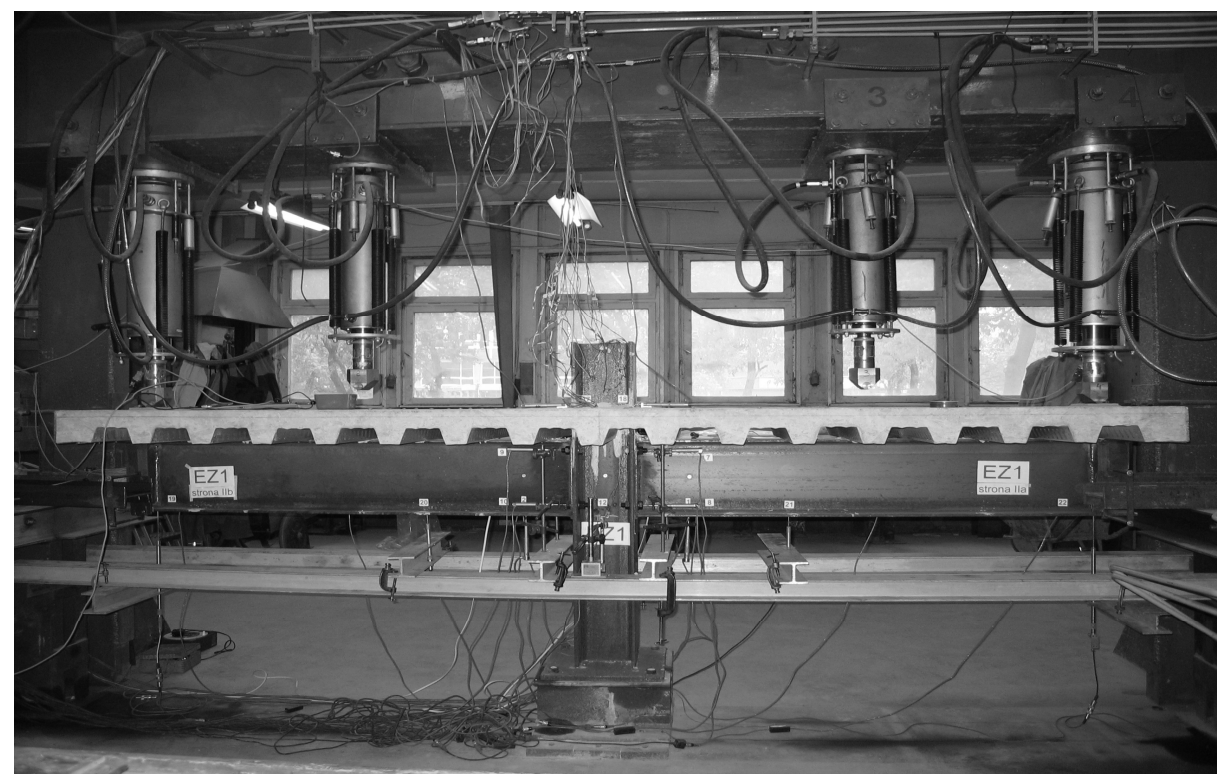

Fig. 1. Test stand and exemplary joint composite specimen prepared for testing

Rys. 1. Stanowisko i przykładowy element z węzłem zespolonym przygotowany do badań

The class of joints considered herein uses end-plates of the thickness ranging from 40 to $60 \%$ of the bolt diameter, $8 \mathrm{~mm}$ to $12 \mathrm{~mm}$, depending upon the diameter of rebars. Such arrangement ensures that the joint failure mode would not be related to the bolt rupture. The concrete slab is cast on the deepprofiled sheeting. Each group of joints is characterized by the same detail of steel parts. The summary of test results of the four respective groups of specimens is presented in Table 1.

Testing was performed with use of equipment existing in the Structures Laboratory of the Faculty of Civil Engineering of the Warsaw University of Technology. Two out of four jacks of the hydraulic system of simultaneous application of the same forces was used in testing. The system guided by the computer was designed in such a way that it may apply, with a high accuracy, four forces of the same magnitude at the same time. The system had been used in tests of specimens with several loads arranged symmetrically. 
Table 1. Tested joints and results of experimentally evaluated joint initial stiffness and moment resistance

Tabela 1. Badane węzły oraz doświadczalnie określone wartości ich sztywności początkowej i nośności

\begin{tabular}{|c|c|c|c|c|c|}
\hline \multirow[t]{2}{*}{ Setting } & \multirow{2}{*}{$\begin{array}{l}\text { Symbol of } \\
\text { tested } \\
\text { specimen }\end{array}$} & \multicolumn{2}{|c|}{ End-plate } & \multicolumn{2}{|c|}{ Joint properties } \\
\hline & & $\begin{array}{c}\text { type } \\
\text { (F: flush; } \\
\text { E: extended) }\end{array}$ & $\begin{array}{l}\text { thickness } \\
{[\mathrm{mm}]}\end{array}$ & $\begin{array}{c}S_{j, i n i} \\
{[\mathrm{kNm} / \mathrm{mrad}]}\end{array}$ & $\begin{array}{c}M_{j, R} \\
{[\mathrm{kNm}]}\end{array}$ \\
\hline \multirow{4}{*}{$\begin{array}{l}\text { Group } 0 \\
(\rho=0)\end{array}$} & ES1 & $\mathrm{F}$ & 10 & 22.63 & 55.52 \\
\hline & ES2 & $E$ & 10 & 44.44 & 92.40 \\
\hline & ES3 & $\mathrm{E}$ & 8 & 37.43 & 62.22 \\
\hline & ES4 & $\mathrm{F}$ & 12 & 27.85 & 64.60 \\
\hline \multirow{4}{*}{$\begin{array}{l}\text { Group 1 } \\
(\rho=0.0060)\end{array}$} & EZ1 & $\mathrm{F}$ & 10 & 46.91 & 123.61 \\
\hline & EZ2 & $\mathrm{E}$ & 10 & 66.89 & 157.28 \\
\hline & EZ3 & $\mathrm{E}$ & 8 & 53.38 & 139.94 \\
\hline & EZ4 & $\mathrm{F}$ & 12 & 48.28 & 133.10 \\
\hline \multirow{4}{*}{$\begin{array}{l}\text { Group } 2 \\
(\rho=0.0135)\end{array}$} & EZ5 & $\mathrm{F}$ & 10 & 56.29 & 178.79 \\
\hline & EZ6 & $\mathrm{E}$ & 10 & 78.19 & 201.18 \\
\hline & EZ7 & $\mathrm{E}$ & 8 & 64.71 & 183.95 \\
\hline & EZ8 & $\mathrm{F}$ & 12 & 60.51 & 187.88 \\
\hline \multirow{4}{*}{$\begin{array}{l}\text { Group } 3 \\
(\rho=0.0035)\end{array}$} & EZ9 & $\mathrm{F}$ & 10 & 36.07 & 90.01 \\
\hline & EZ10 & $E$ & 10 & 50.56 & 126.11 \\
\hline & EZ11 & $\mathrm{E}$ & 8 & 48.50 & 95.00 \\
\hline & EZ12 & $\mathrm{F}$ & 12 & 37.90 & 107.77 \\
\hline
\end{tabular}

Since the estimated single side ultimate load of all the tested joint specimens was lower than the capacity of stronger hydraulic jacks, there was only a need for the application of one stronger jack at each side of tested specimens. The load was applied incrementally in two independent stages, trial and proper. In the first stage, the specimens were loaded incrementally up to about $20 \%$ of the prescribed quasi-plastic strength. This load level was lower than the limit corresponding to the end of the first range of the joint behaviour, namely corresponding to the phase of its quasi-elastic behaviour. During this first stage, all the lack of fit inaccuracies was eliminated so that the second stage of loading would reproduce the real behaviour corresponding to the joint exploitation stage during service. The proper loading program consisted of increments applied statically and monotonically with use of its several magnitudes dependent upon the level of joint response. The static character of loading was assured by keeping a slow speed of the hydraulic jack piston travel. After each load increment, the time interval was applied to allow for a hydraulic system relaxation, and then the readings from all measuring devices were taken and stored for post-processing. 


\subsection{Modes of failure and postlimiting behaviour recorded experimentally}

Different modes of failure were identified in tests. The joint specimens of Group 0 failed with regard to excessive plastic end-plate deformations, greater in case of thinner end-plate specimens than those for thicker ones. In case of steel joints, the force controlled loading program was able to trace their postlimiting behaviour and to produce a sufficient number of records in the range of the joint behaviour above the joint quasi-plastic resistance and under the joint ultimate strength. As a result, the CSD modelling technique based on the least mean square approximation is foreseen to lead to an accurate representation of experimental data. Joint failure resulted in the end-plate to beam weld rupture at the postlimiting range of joint behaviour when endplates exhibited large out-of-plane deformations.

Composite steel-concrete specimens failed in two different modes. In case of Group 3 joints with the smallest reinforcement ratio, the failure was associated with the rebars rupture under the load that might be lesser or greater than that corresponding to the ultimate strength of the appropriate steel joint. The end-plate deformations at this stage were rather small. It was not possible to maintain the load level achieved at the stage of rebars rupture since it was indicative to a drop of the oil pressure recorded in the hydraulic system. The further increase of pressure in the oil supply could not produce a sufficient load increment in order to impose the conditions for the postlimiting behaviour of specimens to take place with already ruptured rebars. Because the rebars rupture was progressive from slab edge towards those placed in the slab closer to the column, and because of a dynamic nature of this process, the further application of force controlled testing procedure resulted in an unstable and insufficient trace of the postlimiting phase of the joint behaviour. As a result, modelling based on the least mean square approximation was foreseen to be less accurate in this case. Rebars rupture was associated with distinctively smaller end-plate deformations than those observed in joints of Group 0 .

Joint specimens of Group 1 failed also due to the rebars rupture undergone at the load level that was higher than the levels recorded for the ultimate strength of their steel counterparts (see Fig. 2). Postlimiting range could be partially traced in experiments of this group of joints and as a result, the wider range of postlimiting joint behaviour was recorded. End-plate deformations at the initiation of rebars rupture of joints of this group exhibited a larger magnitude that those of Group 3, but still were much less than those recorded for joints of Group 0 . This fact was beneficial for modelling in such a way that the experimental data of this group joints would be more suitable for conducting the CSD modelling exercise than the data obtained from tests of Group 3 joints. 


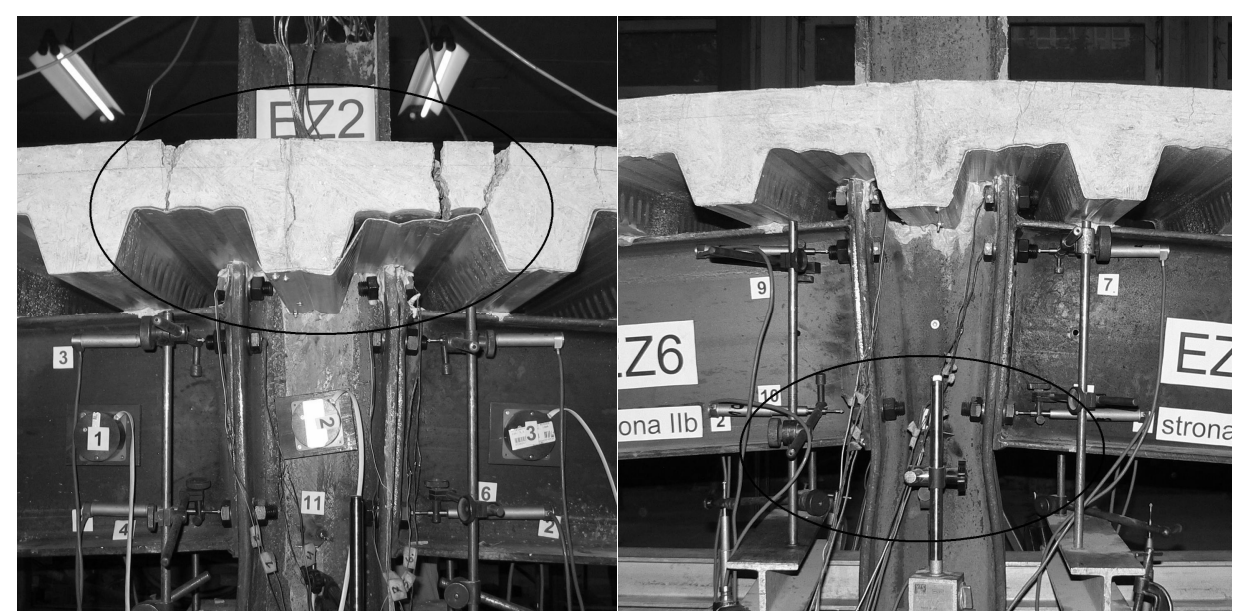

Fig. 2. Modes of failure of joint EZ2 (Group 1) and EZ6 (Group 2) according to [3]

Rys. 2. Modele zniszczenia węzła EZ2 (Grupa 1) i EZ6 (Grupa 2) według [3]

Joint specimens of the Group 2 failed in a different mode than those corresponding to the other steel-concrete joint specimens tested. Since the joint tension zone of this group joints was able to carry a higher resultant force, large cracking of concrete slab was developed but without any further consequences. The high tensile force in the tension zone had to be equilibrated by a high force in the compression zone. In this zone the column web has not been stiffened and as a result it yielded and locally buckled before the rupture of rebars could have taken place (see Fig. 2). Buckled web could not efficiently resist a further increase in the applied load, and the oil pressure in the hydraulic system generating the load dropped down as a visible sign of the failure initiation. The procedure of force controlled test had to be completed so that it did not allow for getting a sufficient number of records in the postlimiting range of the specimen behaviour. The situation was similar to the one related to tests of Group 3 specimens.

End-plate deformations of tested joints were examined after testing. They were cut off carefully from the tested specimens in order to maintain permanent postlimiting deformations in their residual state. Cut-off end-plate specimens were used for the determination of amount of plastic curvatures of deformed end-plates by means of the photogrammetric analysis [8]. This method enabled the reconstruction and 3D-modelling of deformed plate surfaces as well as a presentation of the results in graphic (see Fig. 3) and numerical formats. 


\begin{tabular}{|l|c|c|}
\hline Group & Flush end-plates & Extended end-plates \\
\hline 0 & & \\
\hline 3 & & \\
\hline 1 & & \\
\hline
\end{tabular}

Fig. 3. 3D visualisations of the end-plate surface deformations [8]

Rys. 3. Wizualizacje 3D odkształconych powierzchni blach czołowych [8]

The obtained results of the photogrammetric analysis allowed for an evaluation of the plastic collapse mechanisms of steel and composite joints and also for the determination of yield line patterns, which had been the basis for defining the effective lengths of equivalent $\mathrm{T}$-stub components. The observations supported the relevance of assumptions used for the formulation of Eurocodes' specifications in terms of plastic yield patterns and equivalent properties of $\mathrm{T}$-stub mechanisms. 


\section{Modelling of joint moment-rotation characteristic}

\subsection{Eurocode based models}

The common features of Eurocode based models is that they neglect the effect of joint postlimiting behaviour and are based on a unified piecewise relationship, a linear part in the initial stage, followed by a nonlinear one in the intermediate stage of deformations and finally a horizontal line representing yielding plateau.

\subsubsection{Original Eurocodes DSD formulation}

Eurocode 3 [9] and Eurocode 4 [10] postulate that the behaviour of endplate steel and steel-concrete composite joints may be described analytically by the moment-rotation characteristic of the same format. Moment-rotation characteristics of composite joints are therefore independent from the reinforcement ratio. Mathematical description of the joint characteristic is represented by the following formulae:

- in the quasi-elastic region, i.e. for $M_{j, E} \leq \alpha M_{j, R}$

$$
M_{j, E}=S_{j, i n i} \phi_{E}
$$

- in the inelastic region, i.e. for $\alpha M_{j, R}<M_{j, E}<M_{j, R}$

$$
M_{j, E}=S_{j} \phi_{E}
$$

- and finally in the plastic region, i.e. for $\phi_{E} \geq \phi_{X}$

$$
M_{j, E}=M_{j, R}
$$

where: $M_{j, E}, \phi_{E}$ - joint moment and rotation action effects corresponding to a current stage of applied load level,

$M_{j, R}$ - joint quasi-plastic moment resistance,

$\phi_{X}$ - joint rotation corresponding to the end of inelastic joint behavior and the beginning of joint yielding plateau,

$S_{j, i n i}$ - joint initial stiffness for the joint linear response in the quasielastic region,

$S_{j}$ - joint secant stiffness for the joint nonlinear response in the inelastic region: 


$$
S_{j}=\frac{S_{j, i n i}}{\mu},
$$

$\mu$ - joint stiffness factor for the evaluation of joint secant stiffness for the joint inelastic behaviour:

$$
\mu=\left(\frac{M_{j, E}}{\alpha M_{j, R}}\right)^{\psi} .
$$

Joint behaviour described by the standard joint characteristic described above needs to provide a calibrated model parameters $\alpha$ and $\psi$, see Eq. (5), where the first one is related to the upper limit of joint linear characteristic in the joint quasi-elastic region of its behaviour and the second one - to the shape of the joint characteristic in the inelastic region. The said parameters define the joint rotation $\phi_{X}$ as follows:

$$
\phi_{X}=\alpha^{\psi} \phi_{R}
$$

where: $\phi_{R}=M_{j, R} / S_{j, \text { ini }}$ - reference value of joint rotation.

In the Eurocodes it was assumed that the $\alpha$-parameter represents the ratio of the resultants corresponding to plastic and elastic distribution of joint forces, respectively. It is therefore equal to $2 / 3$, while the other $\psi$-parameter corresponds to the joint secant stiffness that represents about $1 / 3$ of the initial stiffness. It yields therefore the value of this parameter adopted in Eurocode 3 [9]:

$$
\psi=-\frac{\ln 3}{\ln \alpha}=2.7
$$

where: $\ln (x)=\log _{\mathrm{e}}(x)$ - natural logarithm function of the argument $x$, $\mathrm{e}-$ Euler's number. 


\subsubsection{Generalization of Eurocodes DSD formulation}

Experimental investigations conducted at the Warsaw University of Technology have shown that although the shape of steel joint characteristic is well represented by the original Eurocodes approach, the composite joints $M-\phi$ characteristic would strongly be affected by the reinforcement ratio [3]. The study of experimental characteristics obtained for composite joints of Groups 1, 2 and 3 showed that the quasi-elastic region of the behaviour is reduced progressively with the enlargement of reinforcement ratio and the inelastic region is progressively extended beyond that corresponding to the constant value of rotation $\phi_{X}$ of the original Eurocodes DSD formulation. This brought the conclusion that the joint quasi-plastic moment resistance should be related to the variable rotation $\phi_{X}$ dependent upon the reinforcement ratio instead of maintaining its constant value [3]. Since the rotation $\phi_{X}$ was linked directly to the model parameters $\alpha$ and $\psi$ of the standard joint characteristic, the latter were also postulated to be variable parameters with reference to the amount of slab reinforcement over the beam-to-column joint zone of hogging bending.

Observations of the experimentally obtained behaviour of composite joints with highest reinforcement ratio, for which the failure mechanism was ductile, brought research attention to the conclusion that their plastic moment resistance should be calculated for the secant stiffness of being about $1 / 4$ of the initial one, instead of about $1 / 3$ as taken in the original Eurocodes' approach. This resulted in a necessity to correct the values of $\alpha$ and $\psi$ parameters of generalized joint moment-rotation characteristic, namely to adopt $\alpha=4 / 9$ and $\psi=1.7$. Because the experimental study conducted in [3] was rather narrow and based only on one specimen tested for each group of different joint detailing, the linear functions were proposed to vary the model parameters $\alpha$ and $\psi$ of generalized standard Eurocodes characteristic with regard to the reinforcement ratio. It yielded the following relationships:

$$
\alpha=\frac{2}{3}\left(1-\frac{\rho}{3 \rho_{0}}\right) \geq \frac{4}{9}
$$

and

$$
\psi=2.7-\frac{\rho}{\rho_{0}} \geq 1.7
$$

where: $\rho$ - actual value of the slab reinforcement ratio in the joint zone of hogging bending, $\rho_{0}$ - threshold value of the reinforcement ratio. 
The threshold value of $\rho_{0}$ is postulated to be taken as a notional ratio corresponding to such a reinforcement ratio which creates, for the considered joint detailing, a boundary line between the two distinctive failure modes, namely the brittle one initiated by the reinforcement rupture in the steelconcrete tension zone of composite joints and the ductile one, initiated by yielding or yielding and local buckling of components in the steel compression zone of composite joints. Although the parameter $\rho_{0}$ is to be calculated independently for each joint detailing, it was postulated in [3] to operate on its average value of $\rho_{0}=0.01$.

\subsection{CSD model accounting for joint postlimiting behaviour}

As it has been mentioned before, present codification rules and their extensions for the evaluation of joint moment-rotation characteristic disregard the joint post-limiting stiffness. In order to capture the joint progressive stiffness degradation with hardening effect taken into account, the three parametric CSD model is adopted. It is based on a probabilistic considerations of independent linear mechanisms of initial response with the stiffness $S_{j, \text { ini }}$ and the postlimiting response with the rotation hardening stiffness $S_{j, p o s t l i m}=\xi S_{j, \text { ini }}$ (see also [6], [7]). This relationship takes the following form:

$$
M_{j, E}=\left[\left(\frac{1}{S_{j, \text { ini }} \phi}\right)^{n}+\left(\frac{1}{M_{j, R}+\xi S_{j, i n i} \phi}\right)^{n}\right]^{-\frac{1}{n}},
$$

or in a dimensionless format:

$$
\frac{M_{j, E}}{M_{j, R}}=\left[{\frac{\phi}{\phi_{R}}}^{-n}+\left(1+\xi \frac{\phi}{\phi_{R}}\right)^{-n}\right]^{-\frac{1}{n}}
$$

where: $n$ - shape factor of the $M-\phi$ characteristic, $\xi=S_{j, p o s t l i m} / S_{j, i n i}$ - factored hardening modulus.

It is worth to note that for the evaluation of $n$ and $\xi$ of the CSD relationship of joint moment-rotation characteristic, an optimization like procedure is needed to be used together with experimental data available from laboratory tests. Such a procedure is presented in the following section. Results obtained from tests conducted on isolated joints at the Warsaw University of Technology [3] are considered for this purpose. 


\section{Calibration of CSD model parameters of proposed moment- rotation characteristic}

\subsection{Error measure and best fit approximation method}

In case of assessment of the correlation of experimentally recorded joint discrete moment-rotation characteristics, a number of error measures may be suggested to assess the accuracy of proposed analytical CSD model.

In the least mean square approximation used hereafter for the best fit of moment-rotation characteristics of both steel and steel-concrete composite joints, the MSE measure is adopted:

$$
M S E=\frac{1}{m} \sum_{i=1}^{m}\left(M_{\exp , i}-M_{t h, i}\right)^{2}
$$

where: $M_{\text {exp }, i}$ - desired (known) value of the moment obtained for the $i^{\text {th }}$ recorded rotation $\phi_{i}$ from the experiment,

$M_{t h, i}$ - value of the moment obtained from developed CSD model and calculated for the same rotation $\phi_{i}$ as the experimentally $i^{\text {th }}$ recorded,

$m$ - number of recorded sets of $\left(M_{\text {exp }, i} ; \phi_{i}\right)$ for the discrete, experimentally obtained moment-rotation characteristic of the tested joint.

The best fit of CSD model to the experimental moment-rotation curve is investigated by tabulating the points of MSE surface for a number of sets of model parameters $n$ and $\xi$ chosen from the range of $(0 ; 1)$ and $(0 ; 0.1)$, respectively. For each set of parameters, the $M S E$ value is calculated and it represents one point on the MSE surface. Completing the calculations for all the points, the entire MSE surface is constructed for each tested specimen.

The MSE surfaces are shown in Fig. 4 for Group 0 joints, Fig. 5 for Group 1 joints, Fig. 6 for Group 2 joints and finally in Fig. 7 for Group 3 joints. The global minimum of MSE surface corresponds to the best-fitting model parameters with use of which the relationships (10) or (11) reproduce with a highest accuracy the experimental moment-rotation characteristics. 

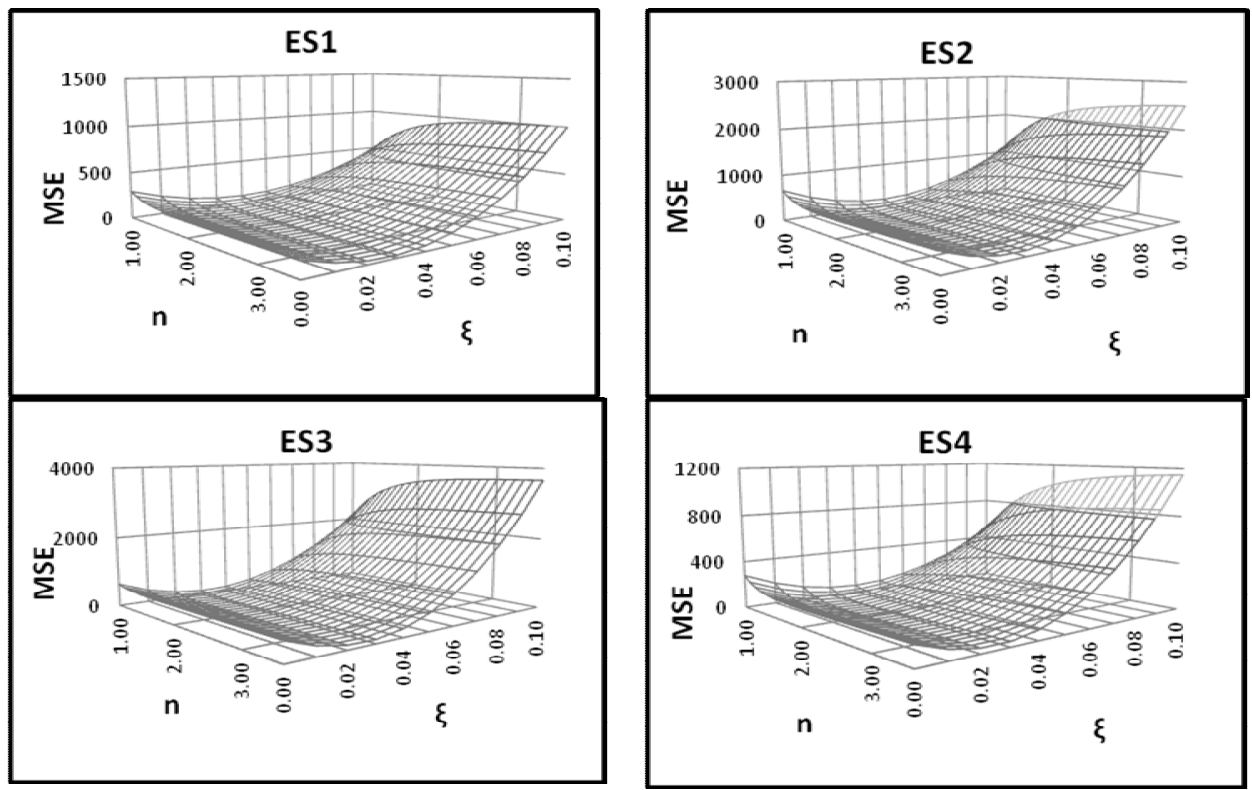

Fig. 4. $M S E$ surface for Group 0 steel joints $(\rho=0)$

Rys. 4. Powierzchnia MSE wyznaczona dla węzłów stalowych Grupy $0(\rho=0)$
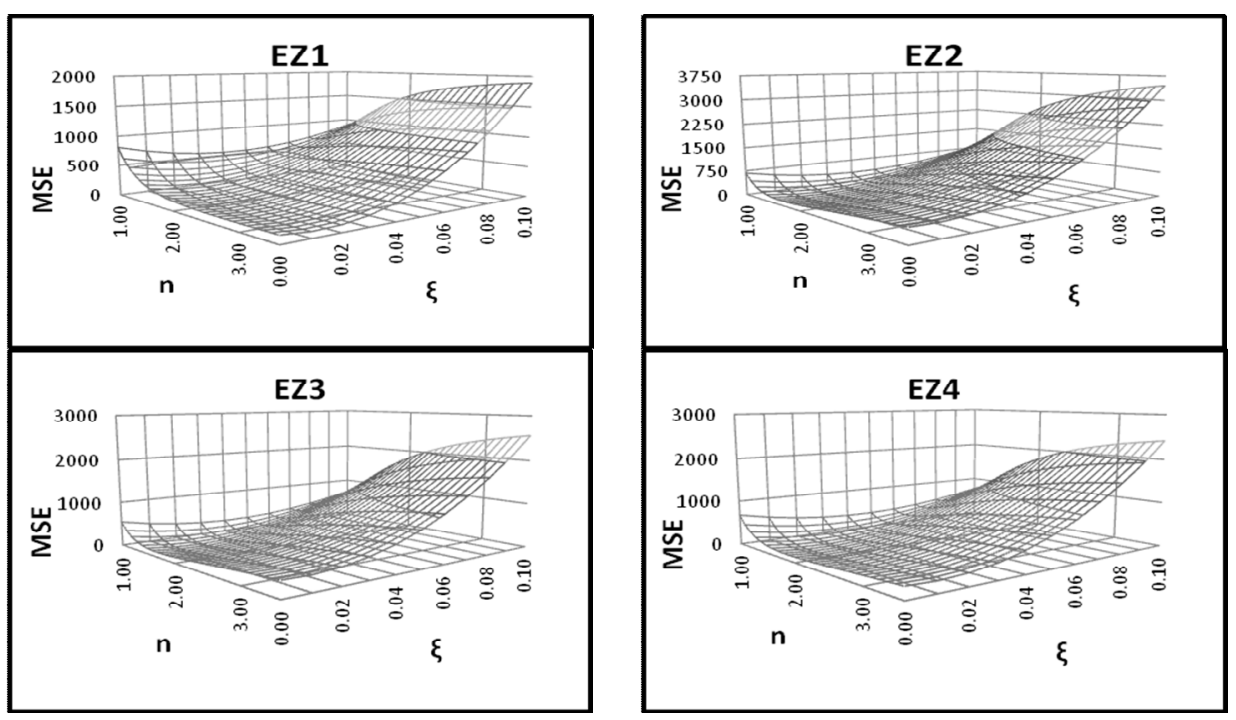

Fig. 5. $M S E$ surface for Group 1 composite joints $(\rho=0.60 \%)$

Rys. 5. Powierzchnia MSE wyznaczona dla węzłów zespolonych Grupy $1(\rho=0.60 \%)$ 

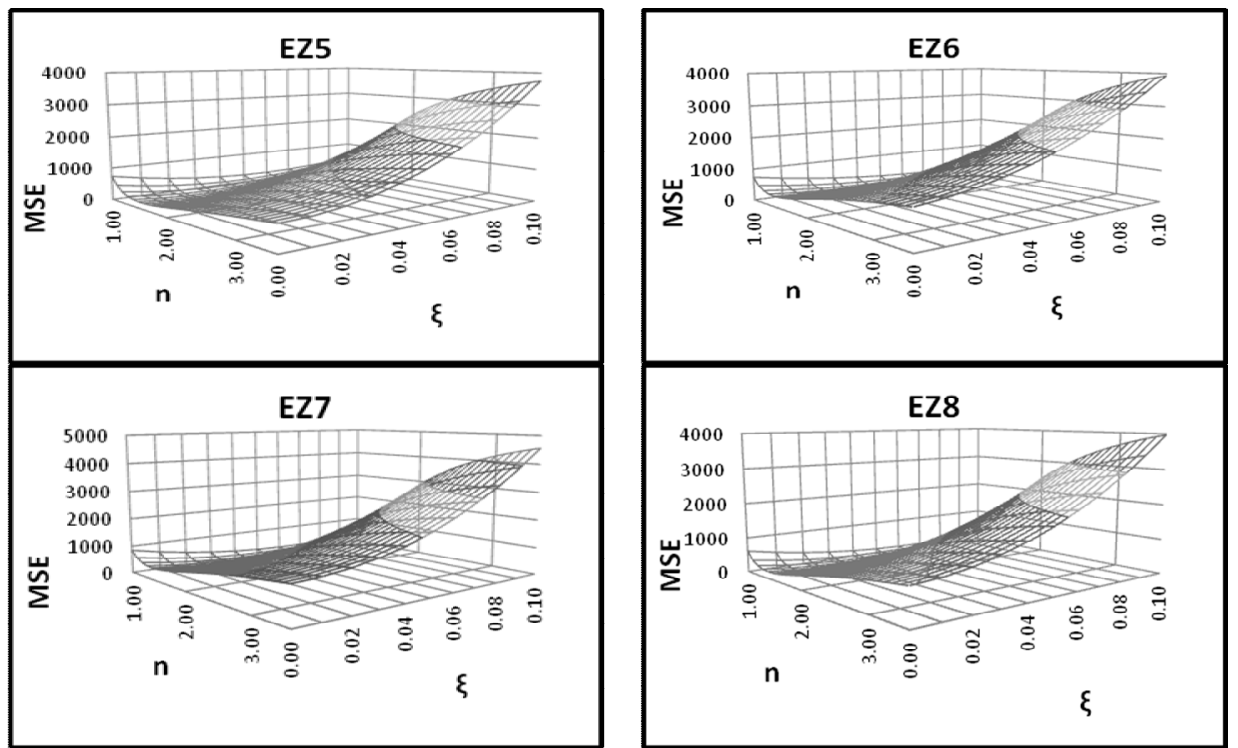

Fig. 6. MSE surface for Group 2 composite joints $(\rho=1.35 \%)$

Rys. 6. Powierzchnia MSE wyznaczona dla węzłów zespolonych Grupy 2 ( $\rho=1.35 \%)$
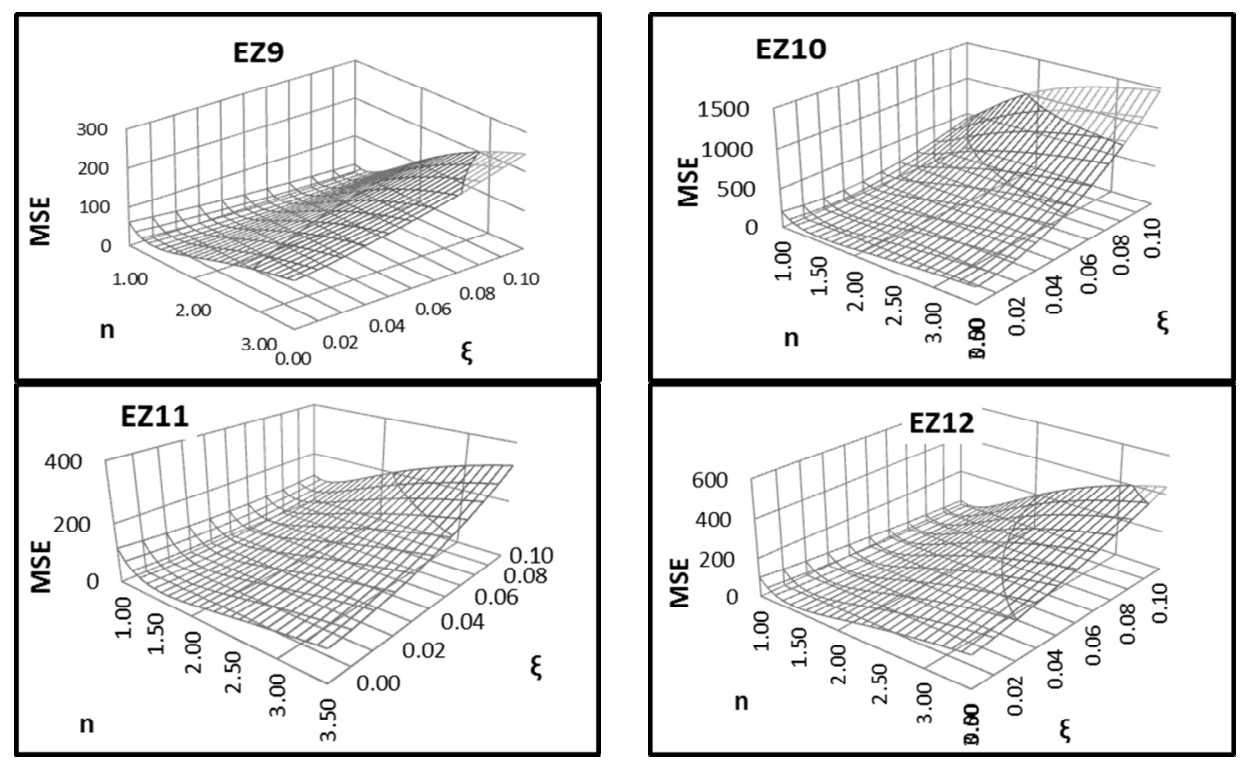

Fig. 7. $M S E$ surface for Group 3 composite joints $(\rho=0.35 \%)$

Rys. 7. Powierzchnia MSE wyznaczona dla węzłów zespolonych Grupy 3 ( $\rho=0.35 \%)$ 


\subsection{Calibration results of CSD model parameters}

For each tested specimen a set of experimentally obtained records $\left(M_{\text {exp }, i} ; \phi_{i}\right)$ for $i=1,2, \ldots, m$ and the number of records $m$ were stored. They are used hereafter for the calibration exercise to find the best fit values of model parameters $\xi$ and $n$. The $\xi$ and $n$ values are first established independently for experimentally obtained characteristics of each joint in Groups 0, 1, 2 and 3. The values of model parameter $\xi$ and $n$ leading to the best fit of $M-\phi$ characteristics of joint Groups 0, 1, 2 and 3 are listed in Table 2.

Table 2. Calibrated model parameters

Tabela 2. Skalibrowane parametry modelu

\begin{tabular}{|l|l|l|l|l|l|}
\hline $\begin{array}{l}\text { Group of } \\
\text { specimens }\end{array}$ & $\begin{array}{l}\text { Specimen } \\
\text { number }\end{array}$ & \multicolumn{2}{|l|}{$\begin{array}{l}\text { Flush end-plate joint } \\
\text { (F) }\end{array}$} & \multicolumn{2}{l}{$\begin{array}{l}\text { Extended } \\
\text { joints (E) }\end{array}$} \\
\hline & & $\xi$ & $n$ & $\xi$ & $n$ \\
\hline 0 & $1(\mathrm{~F}), 2(\mathrm{E})$ & 0.0275 & 2.20 & 0.0292 & 1.66 \\
\cline { 2 - 6 } & $4(\mathrm{~F}), 3(\mathrm{E})$ & 0.0278 & 1.70 & 0.0273 & 1.58 \\
\hline \multirow{3}{*}{1} & $1(\mathrm{~F}), 2(\mathrm{E})$ & 0.0134 & 2.64 & 0.0198 & 1.51 \\
\cline { 2 - 6 } & $4(\mathrm{~F}), 3(\mathrm{E})$ & 0.0184 & 1.70 & 0.0192 & 1.54 \\
\hline \multirow{2}{*}{3} & $5(\mathrm{~F}), 6(\mathrm{E})$ & 0.0270 & 1.34 & 0.0544 & 1.13 \\
\cline { 2 - 6 } & $8(\mathrm{~F}), 7(\mathrm{E})$ & 0.0409 & 1.17 & 0.0463 & 1.14 \\
\hline \multirow{3}{*}{3} & $9(\mathrm{~F}), 10(\mathrm{E})$ & 0.1000 & 1.12 & 0.0110 & 1.46 \\
\cline { 2 - 6 } & $\begin{array}{l}12(\mathrm{~F}), 11 \\
(\mathrm{E})\end{array}$ & 0.1000 & 1.13 & 0.0080 & 1.61 \\
\hline
\end{tabular}

From results obtained in the calibration exercise it is clear that:

(a) identified values of model parameters $\xi$ and $n$ are generally non-unique for specimens of Groups 2 and 3,

(b) the applied approximation method may therefore lead to rather inaccurate results for specimens of Groups 2 and 3 (shaded rows in Table 2).

The non-uniqueness of the obtained solutions is visible in figures illustrating the MSE surface of specimens of these groups. A rather broad and flat bottom of crater or valley path of MSE surfaces may be observed for specimens of Groups 2 and 3 meaning that there are a number of $\xi$ and $n$ pairs giving similar accuracy of the prediction of $M-\phi$ characteristic. The reason for inaccuracy is that the experimental moment-rotation characteristics of specimens belonging to Groups 2 and 3 consist of substantially smaller number $m$ of experimentally obtained sets $\left(M_{\text {exp,i } i} ; \phi_{i}\right)$. This statement is in relation to the postlimiting range of the joint behaviour if compared with its prelimiting range. On the other hand, Groups 0 and 1 are characterized by a sufficient number $m$ of experimentally obtained records in both pre- and postlimiting range of joint rotations. It is therefore postulated that at this stage 
of research the model parameters $\xi$ and $n$ are approximated linearly at the lower bound values obtained for Groups $0(\rho=0)$ and Group $1(\rho=0.006)$, and for specimens with the reinforcement ratio $\rho$ greater than 0.006 the values obtained for $\rho=0.006$ are to be used.

\subsection{Unification of calibrated model parameters}

The specimens of Groups 0, 1, 2 and 3 were treated in calibration exercise as belonging to separate 12 subpopulations. From now on, the main parameter to be considered in CSD modelling of joint moment-rotation characteristic is recognized to be the reinforcement ratio. If so, there is a need to rearrange the subpopulations to create the ones corresponding to the joint group number. Taking a closer look at the values of model parameters for new subpopulations one can conclude that the lowest scatter of model parameters $\xi$ and $n$ is for the subpopulation 0 , while the highest one is for the subpopulations 2 and 3 . This concludes also the previously stated remarks that results obtained from tests conducted using the equipment allowing only for a force controlling procedure are not generally adequate for the evaluation of postlimiting joint behaviour. It is therefore not suitable also for the evaluation of joint rotation capacity that is understood herein as the rotation corresponding to the maximum moment applied to the joint in the postlimiting range of its behaviour (equal to the joint ultimate strength).

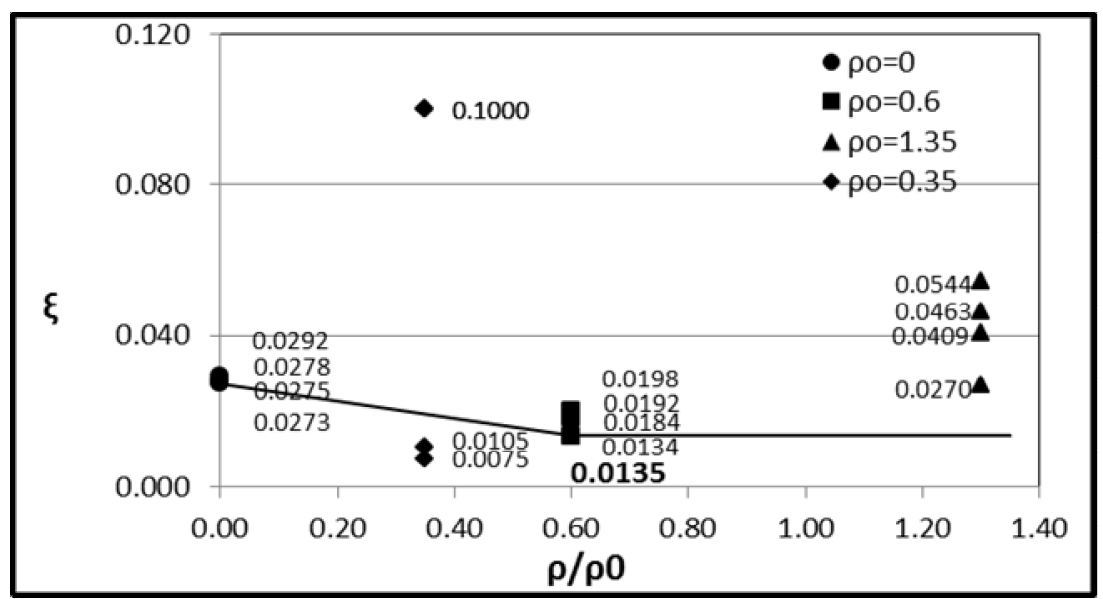

Fig. 8. Proposed function of reinforcement ratio dependent model parameter $\xi$

Rys. 8. Zaproponowana funkcja parametru $\xi$ zależna od stopnia zbrojenia

In order to treat the reinforcement ratio as a deceive parameter for the joint moment-rotation characteristic, and generalize the validation procedure, the values of model parameters $\xi$ and $n$ are therefore evaluated at the lower bound 
level for each newly created subpopulation. The value of $\rho_{0}$ ranges between $0.6 \%$ and $1.35 \%$ for the considered experimental investigations. For simplicity, as it has been stated before, an average value of $\rho_{0}=1.0 \%$ is adopted.

Fig. 8 and Fig. 9 present the proposed linear functions of lower bound approximation of model parameters $\xi$ and $n$ :

$$
\xi=0.0270-0.0227 \frac{\rho}{\rho_{0}} \geq 0.0134
$$

and:

$$
n=1.580-0.115 \frac{\rho}{\rho_{0}} \geq 1.51
$$

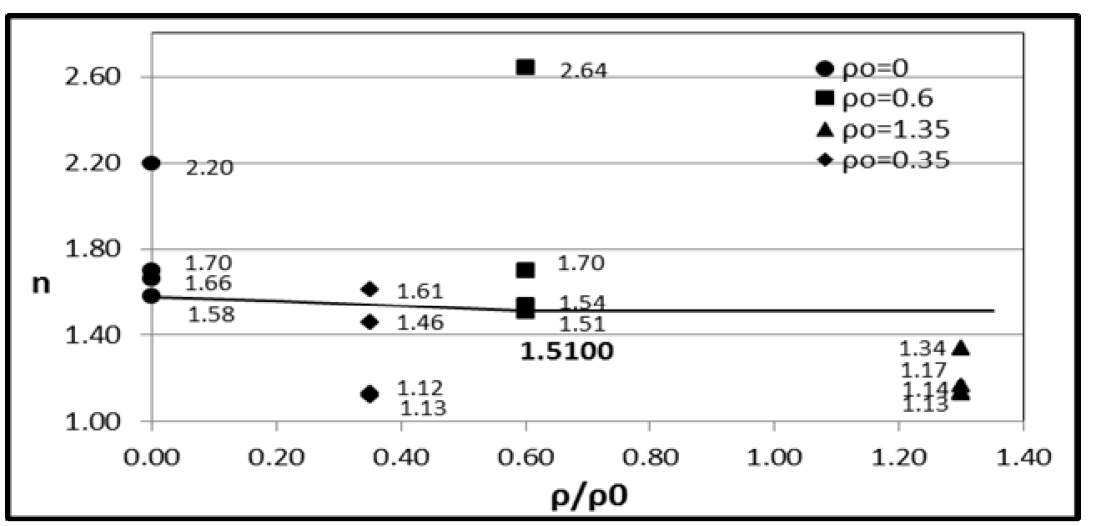

Fig. 9. Proposed function of reinforcement ratio dependent model parameter $n$ Rys. 9. Zaproponowana funkcja parametru $n$ zależna od stopnia zbrojenia

The final values of calibrated parameters according to Eqns. (13) - (14) are used in the following section for the comparison of experimental characteristics and those evaluated according to Eqn. (10).

\section{Verification of developed CSD model of the moment-rotation characteristic of steel and composite steel-concrete joints}

Verification of proposed unified moment-rotation characteristic is made for all tested joints of all the groups, namely Groups $0,1,2$ and 3, with flush and extended end-plates. Results for the flush and extended end-plate joints are presented in Fig. 10 for Group 0 joints, in Fig. 11 for Group 1 joints, in Fig. 12 for Group 2 joints and finally in Fig. 13 for Group 3 joints. 

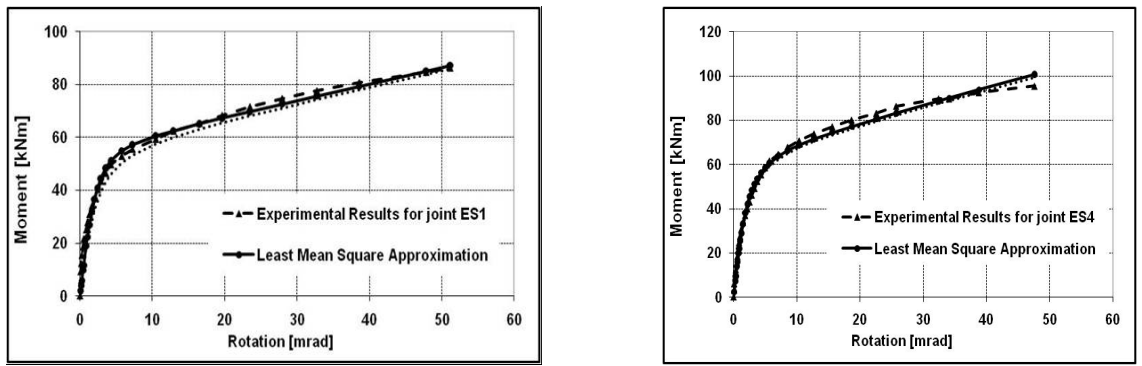

(a) Joints with the flush end-plates
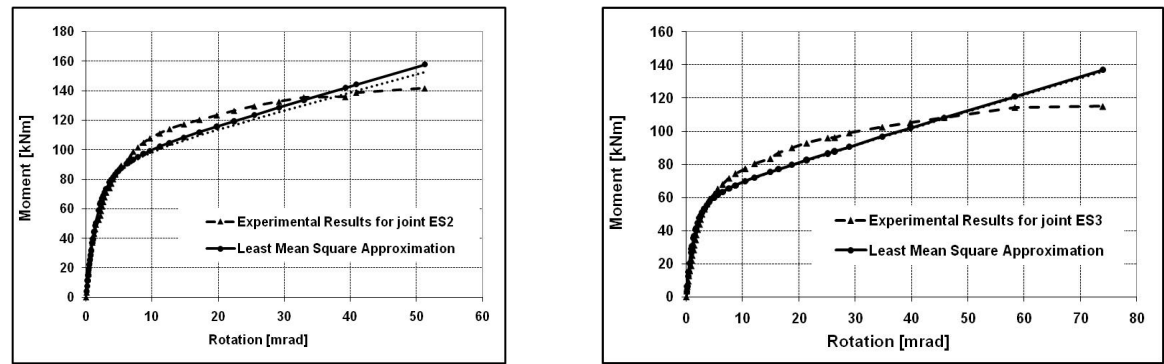

(b) Joints with the extended end-plates

Fig. 10. Comparison of moment-rotation curves for steel specimens ES1-ES4 $(\rho=0)$

Rys. 10. Porównanie krzywych moment-obrót węzłów stalowych w elementach ES1-ES4 ( $\rho=0)$
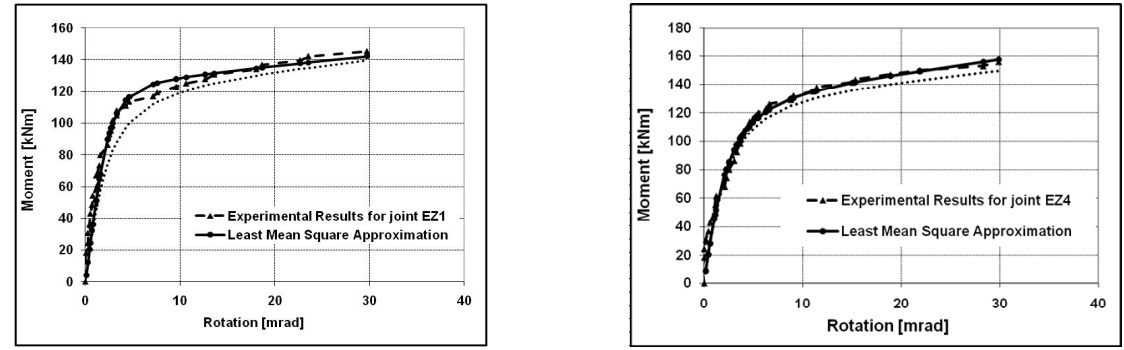

(a) Joints with the flush end-plates
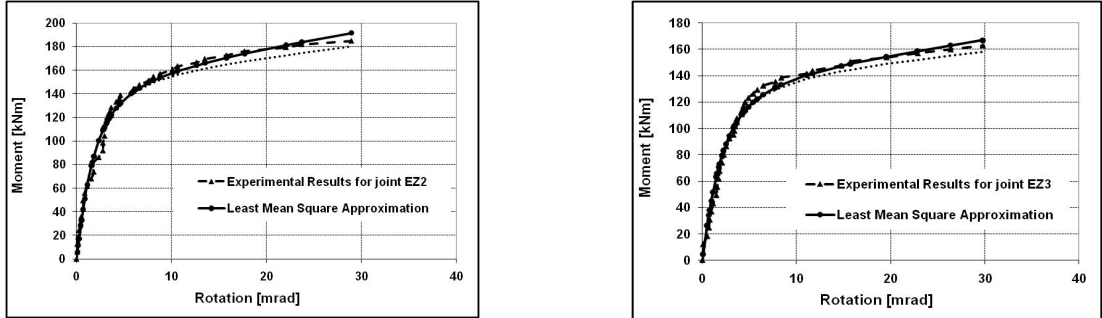

(b) Joints with the extended end-plates

Fig. 11. Comparison of moment-rotation curves for composite specimens EZ1- EZ4 ( $\rho=0.60 \%)$

Rys. 11. Porównanie krzywych moment-obrót węzłów zespolonych EZ1-EZ4 ( $\rho=0.60 \%$ ) 

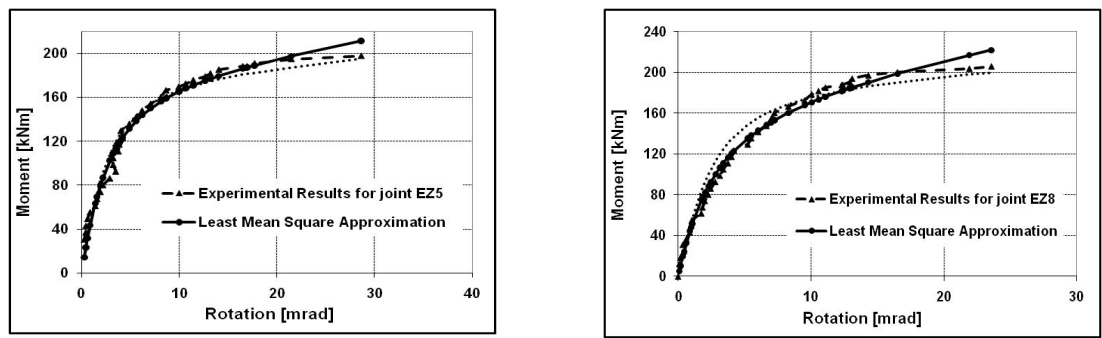

(a) Joints with the flush end-plates
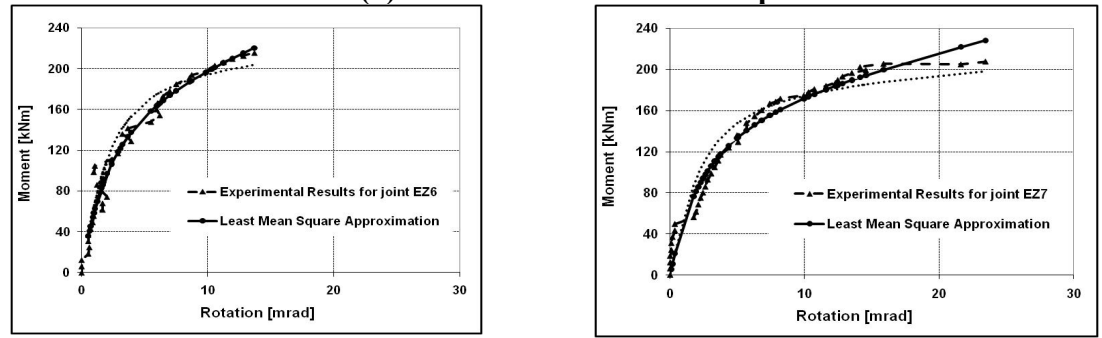

(b) Joints with the extended end-plates

Fig. 12. Comparison of moment-rotation curves for composite specimens EZ5 - EZ8 ( $\rho=1.35 \%)$

Rys. 12. Porównanie krzywych moment-obrót węzłów zespolonych EZ5 - EZ8 ( $\rho=1.35 \%$ )
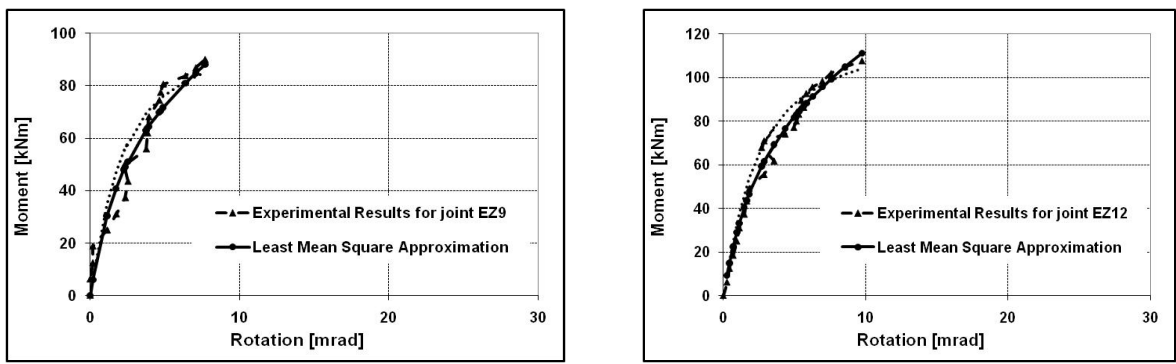

(a) Joints with the flush end-plates
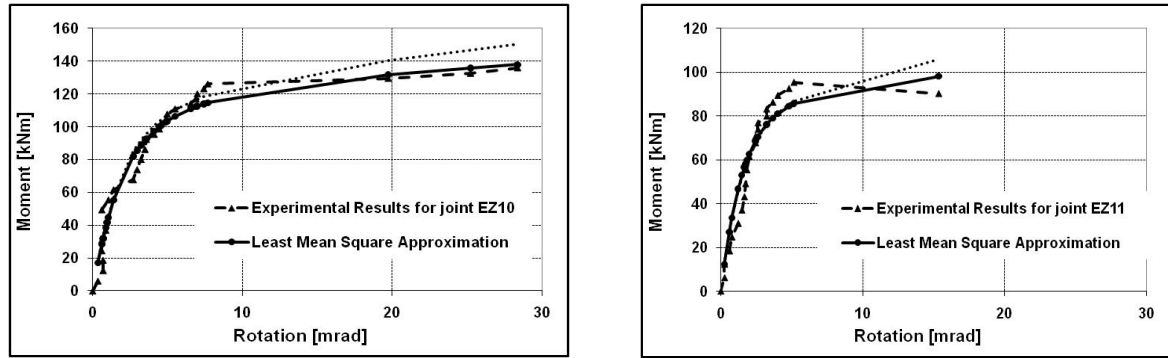

(b) Joints with the extended end-plates

Fig. 13. Comparison of moment-rotation curves for composite specimens EZ9 - EZ12 ( $\rho=0.35 \%)$

Rys. 13. Porównanie krzywych moment-obrót węzłów zespolonych EZ9 - EZ12 ( $\rho=0.35 \%)$ 
The solid line represents in all the figures the results obtained with the model parameters best fitting the experimental moment-rotation characteristics. The dotted line in all the figures represents the results obtained with model parameter according to Eqns. (13) and (14).

A detailed study of Continuous Stiffness Degradation model (CSD model) parameters presented herein with use of the MSE based approximation and experimental results obtained from tests on isolated steel and composite steel-concrete joints is the introductory stage for further research activities conducted with regard to the joint behaviour in frame tests.

\section{Concluding remarks}

The proposed CSD modelling based on MSE approximation method is proven to be a useful tool in the practical evaluation of model parameters in all the cases where there is a sufficient number of records $m$ in the postlimiting range of the joint behaviour. In such a case, the experimental moment-rotation characteristic consists of balanced number of sets $\left(M_{\text {exp }, i} ; \phi_{i}\right)$ recorded in the pre- and post-limiting range of the joint behaviour. The proposed best fit model parameters are therefore based only on the experimental results of joint Groups $0(\rho=0)$ and $1(\rho=0.006)$. The values of model parameters for the reinforcement ratio $\rho=0.0035$ are postulated to be of a linearly interpolated between those for Groups $0(\rho=0)$ and $1(\rho=0.006)$. The values of model parameters for the reinforcement ratio $\rho>0.006$ are postulated to be the same as for $\rho=0.006$.

Comparison of moment-rotation characteristics according to the developed model obtained with use of the calibrated model parameters and the experimentally obtained characteristics shows a good match. It supports the authors' confidence that the proposed approach accounting for the postlimiting stiffness for the evaluation of moment-rotation characteristics of both steel and steel-concrete composite joints adds the value to the on-going research on practical aspects of the behaviour of semi-continuous structural system.

The joint properties based on the experimental moment-rotation characteristic may be evaluated taking into account the general principles adopted in Eurocodes. The initial stiffness $S_{j, i n i}$ is evaluated first for the region of experimental results obtained for the quasi-elastic region, i.e. up to the first visible signs of concrete cracking (in case of hogging bending, i.e. when the reinforced concrete slab is in tension) or crushing (in case of sagging bending, i.e. when the reinforced concrete slab is in compression). The quasi-plastic moment resistance of end-plate joints $M_{j, R}$ is then evaluated for the intersection of the linear relationship based on the initial stiffness that has already been predicted divided by a factor depended upon the reinforcement ratio, and the 
moment-rotation characteristic recorded in tests. The experimental based joint moment-rotation characteristic is then obtained assuming that the linear $M-\phi$ relationship with the initial stiffness $S_{j, i n i}$ starts from its zero value and continuous up to the elastic limit of $\alpha M_{j, R}$, where $\alpha$ is a variable dependent upon the reinforcement ratio of slab in the joint hogging bending zone. Above the elastic limit, the curvilinear power relationship is adopted, in which the power $\psi$ is also a variable value dependent upon the slab reinforcement ratio.

The Eurocode's procedure of experimental $M-\phi$ relationship evaluation and verification of the analytical component method of steel and composite joints with end-plates was generalized within the $\mathrm{PhD}$ study carried out at the Warsaw University of Technology [3] on the basis of experimental program carried out for joints tested in isolation. Studying the sensitivity of moment-rotation characteristic to different parameters of end-plate composite joints, it has been proven that the reinforcement ratio is one of the most influential parameters. This conclusion has been valid for cases of joint configurations with flexible end-plates of thickness being equal to $40-60 \%$ of the bolt diameter. The procedure adopted in Eurocode 4 has been refined in [3] in such a way that parameters $\alpha$ and $\psi$ were considered as variable values dependent upon the reinforcement ratio of the slab taking up tension in the hogging bending zone. Although such an updated procedure has resulted in a better approximation of experimental moment-rotation characteristic by the characteristic based on the refined variable values of parameters $\alpha$ and $\psi$, it would remain unable to reproduce the joint behaviour in an advanced stage of joint deformations. The knowledge of joint behaviour in course of advanced deformations is important for the investigation of joint behaviour in cases of overloading and the assessment of structure potential for redistribution of forces under the activation of alternative loading path.

It is therefore noticeable that the focus in present research is made on the joint behaviour in the region of its overstrength, i.e. for the rotations $\phi>\phi_{X}$, where $\phi_{X}$ is the rotation corresponding to the joint hogging moment resistance $M_{j, R}$. The behaviour of joint is described analytically by the so-called CSD model in which the curvilinear $M-\phi$ relationship based on probabilistic considerations is adopted that leads to a two parametric continuous functions of the joint rotation for both the strength and the tangent stiffness. The parameters of these functions depend upon the conventional joint properties $S_{j, i n i}$ and $M_{j, R}$, as described here above, and the model parameters $n$ and $\xi=S_{j, p o s t l i m} / S_{j, \text { ini }}$ instead of Eurocodes' DSD model parameters $\alpha$ and $\psi$, where $S_{j, p o s t l i m}$ is the postlimiting stiffness. The model parameter $n$ describes the shape of joint characteristic in terms of stiffness deterioration process while $\xi$ is the parameter indicating the degree of overstength. The values of model parameters of this newly proposed formulation are evaluated individually with use of MSE method for each of all joints tested experimentally in isolation [3]. 
Based on this exercise, the approximate values of model parameters for practical applications are evaluated confirming the fact that they must be functions of at least one of the most influential joint behavioural parameters such as the relative reinforcement ratio $\rho / \rho_{0}$, where $\rho_{0}$ is the ratio that for a given joint solution corresponds to the change of failure mechanisms from the one of reinforcement rupture to that of yielding in shear or compression of any steel components.

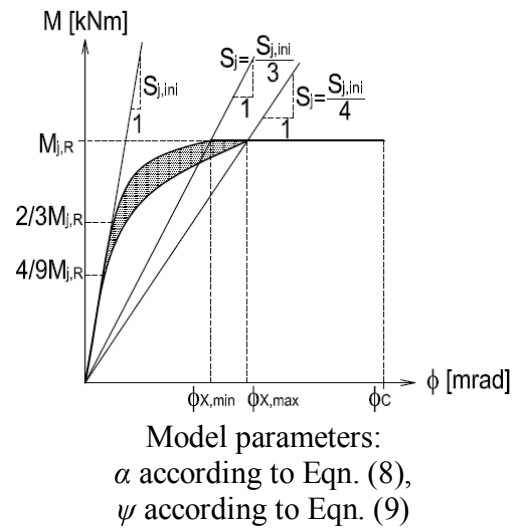

a) Extended Eurocode model proposed in [3]: DSD model.

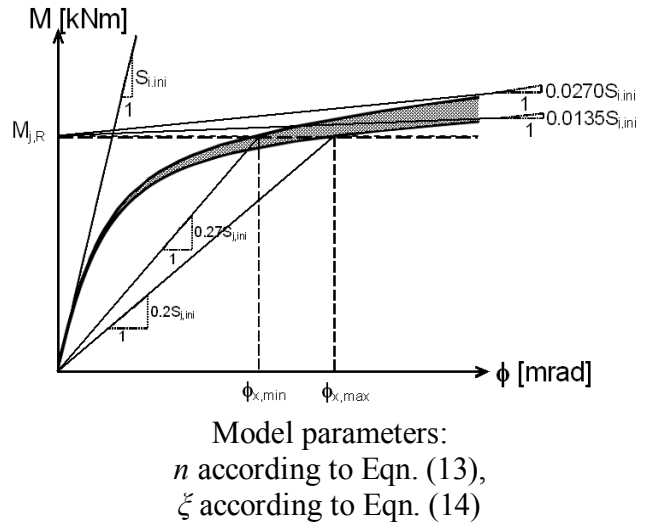

b) Model proposed in [6] and used in this study: CSD model.

Fig. 14. Comparison of analytical modelling of joint moment-rotation characteristic

Rys. 14. Porównanie analitycznego modelowania charakterystyki moment-obrót węzła

Figure 14 gives the comparison of modelling concepts used for the development of generalized moment-rotation characteristic of both the refined Eurocode's approach proposed in [3] of DSD (Discontinuous Stiffness Degradation) and the approach presented herein of CSD (Continuous Stiffness Degradation). The comparison shows clearly that the developed CSD model can account not only for the features of refined Eurocode's model (i.e. the greater inelastic stiffness degradation effect in joints with a higher reinforcement ratio that tends to shift the placement of moment-rotation curve towards larger rotations) but also for the new features affecting the postlimiting behaviour (i.e. hardening stiffness and its dependence upon the relative reinforcement ratio $\left.\rho / \rho_{0}\right)$. It has to be emphasized that for steel joints, for which $\rho / \rho_{0}=0$, the effect of postlimiting stiffness is not vanishing in the CSD model in contrast to that of refined Eurocode's one. 


\section{References}

[1] Giżejowski M., Kozłowski A., Lorenc W.: Modelling of the nonlinear behaviour of steel-concrete composite beams and beam-to-column joints - from theory to practice. Keynote paper: Proceedings of the $12^{\text {th }}$ International Conference on Metal Structures: Progress in Steel and Composite Structures, Wrocław, Poland, 16-17 June 2011. Dolnośląskie Wydawnictwo Edukacyjne, Wrocław 2011, 4-29.

[2] Pisarek Z.: Shaping of joints in composite steel structures, $\mathrm{PhD}$ thesis, Faculty of Civil and Environmental Engineering, Rzeszów University of Technology, Rzeszów 2003 [in Polish - unpublished].

[3] Barcewicz W.: Stiffness, strength and rotation capacity of a certain class of joints in steel structures with composite slabs. PhD thesis, Faculty of Civil Engineering, Warsaw University of Technology, Warsaw 2010 [in Polish - non-referred publication of the Warsaw University of Technology Publishing Office].

[4] Giżejowski M., Saleh B., Kozłowski A., Ślęczka L., Pisarek Z.: Experimental investigations of the frame behaviour subjected to exceptional actions, Zeszyty Naukowe Politechniki Rzeszowskiej, Seria: Budownictwo i Inżynieria Środowiska, zeszyt 59, nr 3/2012/II, 161-168 [in Polish].

[5] Saleh B. A. K.: Modelling of beam-to-column joint of steel-concrete composite frames subjected to standard and extreme load combinations. $\mathrm{PhD}$ thesis, Warsaw University of Technology, Warsaw 2013 [in preparation - non-referred publication of the Warsaw University of Technology Publishing Office].

[6] Giżejowski M., Barcewicz W., Uziak J., Saleh B.: Composite Steel-Concrete Joints for Efficient Applications In Modern Building Structures. Botswana Journal of Technology, vol. 20, no. 1, 2012, 12-24.

[7] Giżejowski M., Barcewicz W., Uziak J., Saleh B.: On evaluation of a unified moment-rotation characteristic of steel and steel-concrete composite joints. Proceeding of $5^{\text {th }}$ International Conference on Structural Engineering, Mechanics and Computation, 2-4 September 2013, Taylor \& Francis, Balkema, 2013 (in press).

[8] Barcewicz W., Giżejowski M.: Photogrammetric analysis of end-plate deformations in steel and steel-concrete composite joints. Zeszyty Naukowe Politechniki Rzeszowskiej, Seria: Budownictwo i Inżynieria Środowiska, zeszyt 58, nr 3/2011/II, 193-200 [in Polish].

[9] Eurocode 3: EN 1993-1, Design of Steel Structures. General rules and rules for buildings.

[10] Eurocode 4: EN 1994-1, Design of composite Steel and Concrete Structures. General rules and rules for buildings. 


\title{
EFEKT NADWYTRZYMALOŚCI WYIZOLOWANYCH WĘZLÓW BELKA-SLUP OBSERWOWANY W BADANIACH STEROWANYCH OBCIĄŻENIEM
}

\begin{abstract}
Streszczen i e
Badania doświadczalne węzłów stalowych i zespolonych stalowo-betonowych wykazały, że charakterystykę moment-obrót węzła można podzielić na trzy zasadnicze zakresy zachowania się, mianowicie: zakres quasi-sprężysty, w którym trwałe odkształcenia lokalne mogą być zignorowane i początkowa sztywność wyznaczona, zakres niesprężysty, w którym następuje sukcesywna redukcja sztywności węzła aż do osiągnięcia nośności węzła rozumianej jako nośność quasi-plastyczna oraz zakres pograniczny, rozumiany jako stan objawiający się nadwytrzymałością węzła. W pracy przedstawiono dyskusję tej problematyki i propozycję modelu obliczeniowego (model CSD), w którym funkcje opisujące charakterystykę węzła w postaci krzywej moment - obrót i jej pierwsza pochodna (sztywność sieczna) są ciągłe i uwzględniają efekt nadwytrzymałości. Wyniki modelowania analitycznego porównano z wynikami badań doświadczalnych przeprowadzonych w Politechnice Warszawskiej. Zakres tych badań obejmował trzy serie elementów badawczych z wyizolowanymi podatnymi węzłami stalowymi i zespolonymi stalowo - betonowymi, łączącymi fragmenty rygli do słupów za pomocą doczołowych połączeń śrubowych ze zlicowanymi i wystającymi blachami czołowymi. Poszczególne serie badawcze były zróżnicowane pod względem stopnia zbrojenia (średnicy prętów zbrojeniowych) płyty stropowej w obszarze działania momentu ujemnego. $\mathrm{Z}$ porównania charakterystyk moment - obrót uzyskanych doświadczalnie $\mathrm{z}$ charakterystykami otrzymanymi na podstawie przedstawionego w niniejszym opracowaniu modelu CSD, z uwzględnieniem skalibrowanych parametrów modelu, uzależnionych od stopnia zbrojenia płyty stropowej w strefie przywęzłowej, wynika, że model ten dobrze odzwierciedla zachowanie się węzłów stalowych i zespolonych.
\end{abstract}

Słowa kluczowe: węzeł stalowy, węzeł stalowo-betonowy, charakterystyka moment-obrót, nadwytrzymałość

DOI: $10.7862 / \mathrm{rb} .2013 .16$

Przestano do redakcji: w maju $2013 r$

Przyjęto do druku: w lipcu 2013 r. 